\title{
Sublethal Concentration of Pyriproxyfen Reduces Testicular Connective Tissue Thickness in Euschistus heros Fabr. (Hemiptera: Pentatomidae)
}

\author{
Janaina F. Matsumoto ${ }^{1}$, Paulo S. G. Cremonez ${ }^{1,2}$, Samuel Roggia ${ }^{3}$, Angela M. F. Falleiros ${ }^{4}$, Sheila M. Levy ${ }^{4}$, \\ Pedro M. O. J. Neves ${ }^{1} \&$ Daniela O. Pinheiro ${ }^{4}$ \\ ${ }^{1}$ Department of Agronomy, State University of Londrina, Londrina, PR, Brazil \\ ${ }^{2}$ Department of Entomology, College of Agricultural and Enrivironmental Sciences, University of Georgia, Tifton, \\ GA, USA \\ ${ }^{3}$ Brazilian Agricultural Research Corporation, Soybean Center (EMBRAPA/Soja), Londrina, PR, Brazil \\ ${ }^{4}$ Department of Histology, State University of Londrina, Campus Universitario, Londrina, PR, Brazil \\ Correspondence: Daniela O. Pinheiro, Department of Histology, State University of Londrina, Campus \\ Universitario, 86057-970, Londrina, PR, Brazil. Tel: 55-43-99179-7267. E-mail: daniela_pinheiro@uel.br
}

Received: May 10, $2021 \quad$ Accepted: June 3, $2021 \quad$ Online Published: August 15, 2021

doi:10.5539/jas.v13n9p27 URL: https://doi.org/10.5539/jas.v13n9p27

The research is financed by the Brazilian National Council for Scientific and Technological Development-CNPq [grant number 133114/2018-0] to JFM, and by the Coordination for the Improvement of Higher Education Personnel—CAPES/Araucaria Foundation [grant number 8882.168655/2018-01] to PSGC.

\begin{abstract}
The aim of this study was to determine the effect of the insecticide pyriproxyfen (Tiger ${ }^{\mathrm{TM}} 100 \mathrm{CE}$ ), juvenile hormone analogue, when applied in a sublethal $\mathrm{LC}_{30}$ concentration $\left(0.668 \mathrm{~mL}\right.$ a. i. $\left.\mathrm{L}^{-1}\right)$, on the morphological and morphometric parameters of external and internal connective tissue (CT) of the Neotropical-brown stink bug Euschistus heros testicles. The insecticide was applied on nymphs from the 4th instar using a Potter tower with a working pressure of $82.73 \mathrm{kPa}\left(12 \mathrm{lb} \mathrm{pol}^{-2}\right)$ and $1 \mathrm{~mL}$ of the emulsion per replicate. A completely randomized experimental design was used, consisting of two treatments (control and pyriproxyfen-treated), five repetitions, and 10 adults of $E$. heros per experimental unit. The insects were maintained under controlled conditions until the emergence of adults. After $48 \mathrm{~h}$ of emergence of adults, the testicles were collected, fixed, and processed for morphological and morphometric analyses. A change was observed in the collagen fibers of the CT of treated insects when compared with those of controls. It was also observed that both types of CT (dense irregular and loose) over the internal tunic of the treated insect were thinner than those in control insects. The analysis showed that pyriproxyfen significantly reduced the external and internal CT width and the conformation of its fibers in all the observed regions when compared with the controls; this may affect the production of the three different types of sperm present in this species.
\end{abstract}

Keywords: collagen, connective tissue, juvenile hormone analogue (JHA), morphogenetic development, side effects

\section{Introduction}

The Neotropical Brown stink bug Euschistus heros (Fabricius, 1798) (Hemiptera: Pentatomidae) is considered an important insect within the pest complex that causes expensive damage in soybean crops in Brazil (Soares, Cordeiro, Santos, Omoto, \& Correa, 2018).

The application of chemical insecticides remains the main control strategy against stink bugs (Corrêa-Ferreira \& Sosa-Goméz, 2017). Among them, pyriproxyfen stands out as a potential alternative to neurotoxic insecticides due to its selectivity based on its mode-of-action as an analogue to the juvenile hormone $(\mathrm{JH})$, which "per se" is naturally produced and secreted by the insect's neuroendocrine system (Nauen, Slater, Sparks, Elbert, \& Mccaffery, 2019). Until now, pyriproxyfen use in Brazilian soybean crops is recommended only for the control of whiteflies (Hemiptera: Aleyrodidae), whose effectiveness is widely recognized (Vieira et al., 2012). 
Regarding the exposure to xenobiotic agents and insecticides, pest insects may develop physiological adaptive aspects at multiple levels (Samantsidis et al., 2020), and this characteristic often has direct effects on the development of the reproductive system, as observed in some pest stink bugs (Aguiar et al., 2017; Cremonez, Pinheiro, Falleiros, \& Neves, 2017). This occurs either by means of resource reallocation in the development of the insect or by the direct action of the insecticide, depending on its mode of action. In that thought, pyriproxyfen may act ultimately as a reproductive system regulator/disruptor, since it has ligand-receptor interactions in the $\mathrm{JH}$ activity chain, a highly related physiological pathway to the gonadotrophic development (K. Li, Jia, \& S. Li, 2019).

The sexual gonads of E. heros are composed of six follicles in each testicle, that exhibit morphological differences among themselves and generates three types of spermatozoa, viz. types I, II, and III (Cossolin, 2015). Spermatozoa are formed in the spermatogenesis process, which denotes cell multiplication, followed by the spermiogenesis process, in which growth, maturation, and spermatid differentiation occurs. Studies with insecticides-treated $E$. heros showed morphometric alteration in the nuclei of testicular accessory cells following exposure to sublethal dosages of chitin biosynthesis inhibitors, indicating a nutritional alteration in spermatozoa formation (Cremonez et al., 2019a). Therefore, it was important to analyze the adjacent connective tissue (CT), that is important for maintaining the follicle structure and responsible for germline cell nutrition.

It is known that the testes are externally covered by a CT capsule that projects inside the interior of the organ, separating each follicle. This tissue has been described in vertebrates as tunica albuginea, although it is referred to as external tunic as similar observed in insects, and its intern ramification are called internal tunics (Souza \& Itoyama, 2010; Alevi, Oliveira, Rosa, \& Oliveira, 2014).

The CT is generally formed of cells and abundant amounts of extracellular matrix, comprising fibrous proteins, such as collagen, reticulin and elastin. That are associated with each other to form a fibrous network, and by a hydrophilic complex of anionic macromolecules and glycoproteins that form the richly hydrated fundamental substance (Geneser, 2004). These tissues also have fixed and transient cells which include fiber-producing cells, such as fibroblasts and fibrocytes, as well as defense cells (Ashhurst, 1982). Connective tissue is responsible for the establishment and maintenance of body shape. This mechanical role is determined by a set of molecules (extracellular matrix) that connects the cells and organs, thus providing support to the body (Mescher, 2018).

Studies on the importance of $\mathrm{CT}$ and its possible alterations have been carried out in relation to several diseases in vertebrates (Kusmirek \& Kanne, 2019). There are a few works that mention alterations in CT in insects (Ashhurst, 1982; Pedersen, 1991; Zara \& Caetano, 2002), although no work mentions morphological and morphometric alterations due to juvenile hormone $(\mathrm{JH})$ analog insecticide contact, like pyriproxyfen.

In this context, the aims of this study were to evaluate the morphological and morphometric alterations in the testicular internal and external $\mathrm{CT}$ of adult $E$. heros males after exposure in late nymphal stage to a sublethal concentration of pyriproxyfen.

\section{Material and Methods}

\subsection{Stink Bug Colony and Maintenance}

Third instar nymphs of $E$. heros were obtained from the permanent stink bug colony in the Entomology Laboratory of Embrapa Soybean (Londrina-PR, Brazil). The nymphs were grouped in polystyrene-crystal boxes $(11 \times 11 \times 3 \mathrm{~cm})$ lined with filter paper, and maintained on a diet based on previously sanitized fresh bean pods (Phaseolus vulgaris L.), peanut seeds (Arachis hypogaea L.), and dried soybean seeds (Glycine max L.) (Depieri, Siqueira, \& Panizzi, 2010).

The insects were kept in controlled conditions $\left(26 \pm 1{ }^{\circ} \mathrm{C} ; 65 \pm 5 \% \mathrm{RH}, 14 \mathrm{~h}\right.$ photophase). Maintenance was performed three times a week, and involved transferring the insects to clean boxes on a new diet.

\subsection{Application of Treatments}

The insecticide application was performed as described by Cremonez et al. (2019b). Briefly, groups of 10 nymphs in the fourth stage (N4) were placed in glass Petri dishes $(9 \mathrm{~cm}$ diam.) and sprayed with $1 \mathrm{~mL}$ of a predetermined sublethal $\mathrm{LC}_{30}$ concentration of pyriproxyfen (Tiger ${ }^{\mathrm{TM}} 100 \mathrm{CE}$ ) of $6.68 \mathrm{~mL} \mathrm{~L}^{-1}$ with the aid of an automatic Potter tower (Burkard Scientific) at a working pressure of $82.73 \mathrm{kPa}$. For control treatment, only pure distilled water was applied. After adult emergency, the males were identified and placed individually in acrylic Petri dishes in the same conditions and on the same diet as described above. 


\subsection{Collection and Processing of Testicles}

Adult males at $48 \mathrm{~h}$ after emergence were anesthetized by cooling $\left(-4{ }^{\circ} \mathrm{C}\right)$ and dissected under a stereoscopic microscope (20x) (Olympus ${ }^{\circledR}$ SZ61). The testes were collected and immediately submerged in the Karnovsky fixative solution $(1: 19 \mathrm{v} / \mathrm{v})$ (glutaraldehyde $2.5 \%$ + paraformaldehyde $4 \%$ in phosphate buffer $0.1 \mathrm{M}, \mathrm{pH} 7.2)$ for $24 \mathrm{~h}$.

After fixation, the testes were dehydrated in an increasingly graduated concentration (70, 90, and $100 \%)$ of ethyl alcohol and dipped in glycol-methacrylate (GMA) resin (Leica ${ }^{\circledR}$ Historesin) + ethyl alcohol $95 \%(1: 1 \mathrm{v} / \mathrm{v})$ at 25 ${ }^{\circ} \mathrm{C}$ for $4 \mathrm{~h}$. The testes were subsequently transferred to an infiltration solution (basic GMA + activator) for an additional $24 \mathrm{~h}$, and finally encased in resin blocks.

The blocks were sectioned $(5 \mu \mathrm{m})$ in a rotary microtome (Leica $\left.{ }^{\circledR} \mathrm{RM} 2145\right)$. The slides with the material were obtained and stained with hematoxylin-eosin dye.

\subsection{Morphometrics of the CT}

The slides were analyzed and photographed in a Zeiss Axiophot ${ }^{\circledR}$ microscope coupled with a Moticam ${ }^{\circledR} 3.0$ MP (Motic). The histological sections of the testicles were analyzed morphometrically using the ImageJ software, according to the methodology proposed by Baviskar (2011).

Six testicles from each treatment were measured, wherein the width $(\mu \mathrm{m})$ of the testicular CT was measured. In the external CT covering (E), also known as peritoneal sheath (Alevi, Oliveira, Rosa, \& Oliveira, 2014), six measurements were taken in the most apical point of each follicle in the tunica externa (Te1-Te6). In addition, similar analyses were performed on the tunica propria at two different regions in the CT between each follicle (Ti1-Ti5) categorized as apical (a), close to the spermatogonia cysts, and basal (b), situated near the vas efferens (Figure 1).

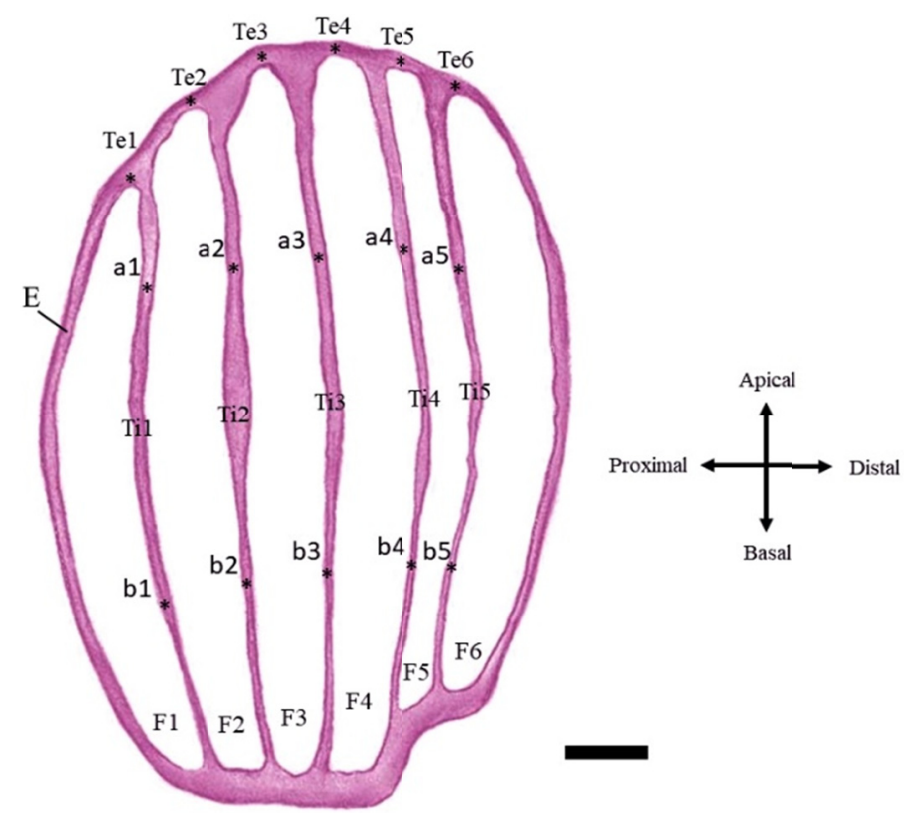

Figure 1. Schematic transversal section of Euschistus heros testicle showing the connective tissue measurement points $(*) . \mathrm{F} 1-\mathrm{F} 6=$ follicles; Ti1-Ti5 $=$ internal connective tissue (tunica propria); Te1-Te6 = external connective tissue (tunica externa); $\mathrm{E}=$ external connective tissue; a1-a5 = measurement points taken in the apical region; b1-b5 = measurement points taken in the basal region. Germline cells not shown. Bar $=0.1 \mathrm{~mm} ;=$ organ sectioning orientation, indicating the apical, basal, proximal, and distal regions

\subsection{Statistical Analysis}

The statistical analysis for morphometry followed the completely randomized design with two treatments (control and $\mathrm{LC}_{30}$ pyriproxyfen-treated) and the six follicles that were analyzed. Assumption of normality and variance homoscedasticity was performed a priori using the Shapiro-Wilk and Levene tests, respectively. Analysis of variance followed by Tukey test $(\mathrm{p} \leq 0.05)$ were performed to compare the measurement points 
within the portions (external, apical and basal) in each treatment. The treatments per se were compared using Student's t-test with the statistical software $\mathrm{R}^{\circledR}$ (R Core Team, 2019).

\section{Results}

It was observed the six follicles (namely $\mathrm{F} 1$ to $\mathrm{F} 6$ ) that constitute the testicles of $E$. heros and the five internal tunica propria (denominated from Ti1 to Ti5) separating these follicles. The testicle was externally coated by the external sheath (E) composed of well-stained CT proper (Figure 2). Each follicle has germline cell cysts at different developmental stages which are involved in the formation of spermatozoids that develop from the apical to the basal region (Figures 2A-2C). Each follicle is separated by CT (Ti), with a total of five internal walls, with $\mathrm{F} 1$ being the more proximal and $\mathrm{F} 6$ the more distal region (Figure 2B).

In the untreated insects, the external $\mathrm{CT}$ was formed in the external $\mathrm{CT}$ sheath by strongly eosin-stained, dense, thick fibers, placed in a random arrangement which is very characteristic of collagen fibers (Figure 2A). Elongated fibroblast nuclei were also observed among the defense cells (Figure 2B). The internal CT lining the follicles that generate spermatozoa type I (F1, F2, and F3), compared with types II (F5) and III (F4 and F6), did not present evident morphological variations. No changes were observed between the external CT on apical and basal regions.

In pyriproxyfen-treated stink bugs, thinner fibers were observed in the external sheath (Figure 2C), unlike the dense and thick fibers observed in the same relative spot in untreated insects (Figure 2A). This reduction was also observed in internal CT in the apical position of most analyzed insects. The transition point between dense CT was not modeled with the loose CT in Ti2 and Ti3, which intercalate F2-F3 and F3-F4, respectively. In some cases, a general alteration of the internal CT was observed (Figure 2A), whereas in others, it was possible to note the transition region where the alteration occurred (Figure 2D). 

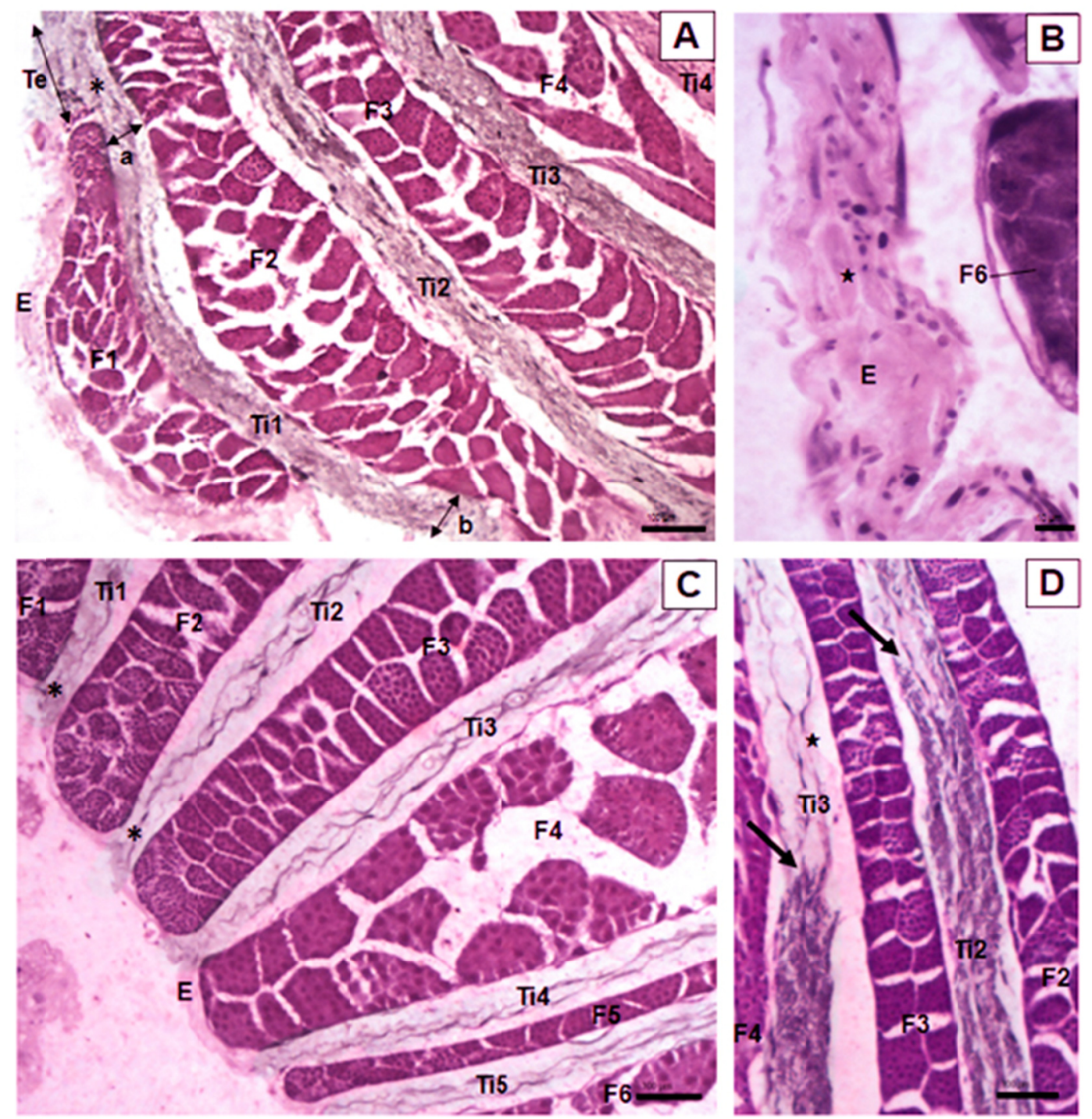

Figure 2. Photomicrograph showing testicles of adult Euschistus heros stained with Hematoxylin-Eosin. (A)-(B): Untreated (control) insects. (C)-(D): Pyriproxyfen $\mathrm{LC}_{30}$ treated insects. (A)-(C): Note external connective tissue

(E) covering the organ; (A)-(D): Testicular follicles numbered F1-F6 with spermatozoa in formation and germline cells cysts inside. (A), (C), \& (D): Connective tissue wall between follicles numbered Ti1-Ti5 showing the measured points ( ). (A) \& (C): Note testicular septa $(*)$, projections of the external tunic that divide the follicle in the internal connective tissue walls. (B): Detail of the external connective tissue covering the testicle; Note collagen fiber $(\star)$ of dense irregular (non-modeled) connective tissue. (D): Detail of the alteration (arrow) of the collagen fiber $(\star)$ of the internal connective tissue along the wall

The internal CT is not homogenous in thickness, i.e., present a high variation in its structure. Regardless, the average thickness on the homologous measurement points were not significantly different from each other both in apical and basal regions of untreated $\left(\mathrm{F}_{[4.25]}=1.60, \mathrm{p}=0.205\right.$ and $\left.\mathrm{F}_{[4.25]}=2.89, \mathrm{p}=0.052\right)$ and pyriproxyfen-treated testicles $\left(\mathrm{F}_{[4.25]}=0.56, \mathrm{p}=0.693\right.$ and $\left.\mathrm{F}_{[4.25]}=2.50, \mathrm{p}=0.068\right)$, respectively. However, the external covering is considerable different in some homologous points from untreated $\left(\mathrm{F}_{[5,30]}=3.88, \mathrm{p}=0.008\right)$ and pyriproxyfen-treated testicles $\left(\mathrm{F}_{[5,30]}=5.16, \mathrm{p}=0.002\right)($ Table 1$)$. 
Table 1. Morphometrics of external and internal testicular connective tissues of adult Euschistus heros treated with sublethal concentration of pyriproxyfen in the $4^{\text {th }}$ instar stage $\left(26 \pm 1^{\circ} \mathrm{C}, 65 \pm 5 \% \mathrm{RH}, 14 \mathrm{~h}\right.$ photophase $)$

\begin{tabular}{|c|c|c|c|c|c|c|c|}
\hline Region & & $\begin{array}{l}\text { Control } \\
\text { (pure distilled } \mathrm{H}_{2} \mathrm{O} \text { ) }\end{array}$ & $\begin{array}{l}\text { Pyriproxyfen } L C_{30} \\
\left(=0.688 \mathrm{~mL} \text { a. i. } \mathrm{L}^{-1}\right)\end{array}$ & $\begin{array}{l}\text { Average } \\
\text { reduction (\%) }\end{array}$ & Student's t & p-value & Dif \\
\hline \multicolumn{8}{|c|}{ External connective tissue thickness $(\mu m \pm S E)$} \\
\hline \multirow{6}{*}{ External } & $\mathrm{Te} 1$ & $61.82 \pm 6.80 \mathrm{ab}^{1}$ & $15.85 \pm 1.87 \mathrm{a}$ & 74 & $4.29^{2}$ & 0.0016 & $* *$ \\
\hline & $\mathrm{Te} 2$ & $68.93 \pm 5.85 \mathrm{a}$ & $10.00 \pm 1.51 \mathrm{~b}$ & 85 & 5.95 & 0.0001 & $* *$ \\
\hline & Te3 & $62.90 \pm 5.96 \mathrm{ab}$ & $11.63 \pm 1.32 \mathrm{ab}$ & 81 & 5.31 & 0.0003 & $* *$ \\
\hline & $\mathrm{Te} 4$ & $44.33 \pm 7.67 \mathrm{ab}$ & $8.83 \pm 1.66 b$ & 80 & 3.56 & 0.0052 & $* *$ \\
\hline & Te5 & $57.21 \pm 8.60 \mathrm{ab}$ & $16.15 \pm 2.91 \mathrm{a}$ & 72 & 3.97 & 0.0026 & $* *$ \\
\hline & Te6 & $35.16 \pm 1.77 \mathrm{~b}$ & $10.94 \pm 2.48 \mathrm{ab}$ & 69 & 5.52 & 0.0003 & $* *$ \\
\hline \multicolumn{8}{|c|}{ Internal connective tissue thickness $(\mu m \pm S E)$} \\
\hline & Ti1 & $71.19 \pm 7.74$ & $35.89 \pm 6.83$ & 50 & 2.55 & 0.0287 & $*$ \\
\hline & $\mathrm{Ti} 2$ & $89.15 \pm 10.80$ & $37.30 \pm 7.84$ & 58 & 3.33 & 0.0076 & $* *$ \\
\hline \multirow[t]{5}{*}{ Apical } & Ti3 & $77.59 \pm 7.63$ & $30.28 \pm 5.87$ & 61 & 3.89 & 0.003 & $* *$ \\
\hline & Ti4 & $56.04 \pm 8.24$ & $28.66 \pm 4.35$ & 49 & 2.16 & 0.0559 & ns \\
\hline & Ti5 & $53.05 \pm 9.42$ & $23.82 \pm 3.59$ & 55 & 2.64 & 0.0247 & $*$ \\
\hline & Ti1 & $41.95 \pm 12.10$ & $13.85 \pm 3.14$ & 67 & 2.46 & 0.0334 & $*$ \\
\hline & Ti2 & $34.84 \pm 7.09$ & $14.09 \pm 2.19$ & 60 & 2.74 & 0.0208 & $*$ \\
\hline \multirow[t]{3}{*}{ Basal } & Ti3 & $32.54 \pm 7.68$ & $19.04 \pm 4.82$ & 41 & 1.98 & 0.0762 & ns \\
\hline & Ti4 & $20.73 \pm 3.98$ & $14.84 \pm 3.14$ & 28 & 2.52 & 0.0305 & $*$ \\
\hline & Ti5 & $20.22 \pm 2.33$ & $12.72 \pm 2.23$ & 37 & 3.34 & 0.0075 & $* *$ \\
\hline
\end{tabular}

Note. ${ }^{1}$ Means followed by the same letter in the column do not differ statistically among themselves, Tukey test $(\mathrm{p} \leq 0.05) .{ }^{2}$ Mean values compared by Student's t-test. Dif $=$ difference level: *significant at $p \leq 0.05$; ** significant at $\mathrm{p} \leq 0.01 ; \mathrm{ns}=$ non-significant. $\mathrm{LC}_{30}=$ sublethal concentration. a. $\mathrm{i} .=$ active ingredient. $\mathrm{n}=240$. $\mathrm{Te}=$ External connective tissue tunic. $\mathrm{Ti}=$ internal connective tissue tunic.

Morphometrically, there was a decrease in the width of the external and internal CT in all regions of the testicles of pyriproxyfen-treated insects when compared with those in the control treatment.

The morphometric analysis showed that in pyriproxyfen-treated insects, there was an average reduction of $77 \%$ $(69-85 \%)$ in the width of the external sheath. There was a reduction in the CT width of up to $61 \%$ in the apical region and up to $67 \%$ at the basal region.

\section{Discussion}

The observed alterations in the testicular CT after sublethal pyriproxyfen exposure indicate a possible interference in collagen biosynthesis, in a way that prevents the aggregation of fibrils in the fiber formation, or even the disruption of collagen fibers. The CT is predominantly formed of collagen fibers and these depend on the aggregation of collagen fibrils. It is known that its biosynthesis occurs in several phases, both intracellularly and extracellularly (Ashhurst, 1982). There are 20 types of collagen described in the literature associated with several functions, with types I, II, and III being the most common, mostly found in vertebrates (Mescher, 2018). Collagen type I is predominantly present in the dermis, tendons, and organ and bone capsules. Type II is abundant in the cartilages and type III in the cardiovascular system, lungs, skin, bone marrow, and other tissues (Reddi, R. Gay, S. Gay, \& Miller, 1977; Hanifi, Mccarthy, Roberts, \& Pleshko, 2013).

In insects, type IV collagen is more frequently reported in the literature, being a tri-helical molecule and a structural component of the basal membrane of CT, and has distinct functions that have been already identified (Wilmes, Klinke, Rotstein, Meyer, \& Paululat, 2018 and references therein). In fact, this is the most peculiar type of collagen present in the basement membrane, which together with other components confer a characteristic dynamic status, important for processes of cell division and structure development (Pederson, 1991). However, it is not known which type of collagen is present in the testes of E. heros and thus it is not possible to determine pyriproxyfen mode of action in this system. This is the first report of the general structure composition and morphometrics of testicular connective tissue in this species, and investigative works to evaluate fertility effects of these alterations may be conducted in the future. 
Pyriproxyfen functions as a JH analogue (IRAC group 7A), being classified as an insect growth regulator, also known as insect growth disruptor (IGD), and its application induces the $\mathrm{JH}$ presence in abnormal amounts that induces a non-controlled activity in the target insect (Pener \& Dhadialla, 2012). It is known that secondary and tertiary effects of pyriproxyfen are related to other functions of $\mathrm{JH}$ in insects, such as vitellogenin metabolism, reproductive system structure, regulation of diapause, and hemolymph macro-element homeostasis (Cremonez et al., 2019b; Manaboon, Yasanga, Sakurai, \& Singtripop, 2012; Guo et al., 2014). However, no direct action of this insecticide or the $\mathrm{JH}$ has been previously reported on the formation or the structuring of the CT proper, as indicated in this study.

The morphometric analysis indicated that there was a significant reduction in the thickness of the external sheath in pyriproxyfen-treated insects, thus indicating a loss in the CT coating on the organ capsule. In the apical region of the internal CT, where the spermatogonia are concentrated and the beginning of the germ cell lineage, four of the five studied walls showed a reduction in thickness, and the same occurred in the basal region of the testis. In a similar study using chitin biosynthesis inhibitors, a general apparent size reduction of $E$. heros testes was observed, as well as a reduction in nuclei of testicular accessory cells, evidencing the effect of this IGD on spermatogenesis (Cremonez et al., 2019a).

Recently, our research group conduced a E. heros testicular geometric morphometrics study, and observed a pattern of development adult males with different ages; basically, it was possible to observe a general increase in size up to 10 days old adults, followed by a peculiar hypertrophy in the testicular apical region (Cremonez et al., 2020, personal communication, data non published). Interestingly, pyriproxyfen did reduced the apparent external testicular area in adults of latest observations (10 and 15 days old). These results may be complimentary for the findings in connective tissue alterations.

The non-reduction observed in the Ti3 of the basal region and the Ti4 in the apical region may indicate that the F4 follicle, located between them and responsible for type-III spermatozoid production, has not been affected. Ultimately, the implications of the action of pyriproxyfen on the structure of connective tissue in the basement membrane of the testicular structure can be directly associated with the reproductive potential of the pest.

\section{Conclusion}

Sublethal concentration of the so-called biorational insecticide pyriproxyfen applied in late nymphal stages reduces the thickness of both internal and external testicular connective tissue of adult $E$. heros. The insecticide may have caused a disruption or non-organization of the collagen fibers of the tissue in E. heros testicular development, which ultimately may impact sexual performance.

\section{Acknowledgements}

The authors thank the collaborators Brenda E. P. Alves for creating the schematic draw; the Brazilian Agricultural Research Corporation (EMBRAPA Soybean) for supplying the insects used in this experiment; and the staff of the Department of Histology — UEL and the Laboratory of Pathology and Microbial Control—UEL.

\section{References}

Aguiar, R. C. M., Husch, P. E., Gallo, R. B., Levy, S. M., Vilas-Bôas, L. A., Da Silva, C. R. M., ... Rosa, R. (2017). Effects of thiamethoxam and lambda-cyhalothrin on spermatogenesis of Euschistus heros (Heteroptera: Pentatomidae). Entomol. Sci., 20(1), 279-287. https://doi.org/10.1111/ens.12257

Alevi, K. C. C., Oliveira, J., Rosa, J. A., \& Oliveira, M. T. V. A. (2014). Coloration of the testicular peritoneal sheath as a synapomorphy of triatomines (Hemiptera, Reduviidae). Biota Neotrop., 14(4), 1-3. https://doi.org/10.1590/1676-06032014009914

Ashhurst, D. E. (1982). The structure and development of insect connective tissues. In R. C. King \& H. Akai (Eds.). Insect Ultrastructure (Vol. 1). Springer Science \& Business Media, New York, US. https://doi.org/ 10.1007/978-1-4615-7266-4_11

Baviskar, S. N. (2011). A quick \& automated method for measuring cell area using ImageJ. Am. Biol. Teach., 73(9), 554-556. https://doi.org/10.1525/abt.2011.73.9.9

Corrêa-Ferreira, B. S., \& Sosa-Gomez, D. R. (2017). Percevejos e o sistema de produção soja-milho. Londrina: Embrapa Soja.

Cossolin, J. F. S. (2015). Polimorfismo e ultraestrutura dos espermatozoides de Euschistus heros (Fabricius, 1798) (Hemiptera: Pentatomidae) (Dissertation, Universidade Federal de Viçosa, MG, Brazil). 
Cremonez, P. S. G., Gouvea, S. P., Pinheiro, D. O., Falleiros, A. M. F., Levy, S. M.; Meneghin, A. M., ... Neves, P. M. O. J. (2019a). Chitin Biosynthesis Inhibitors in Euschistus heros Fabr. (Hemiptera: Pentatomidae): Morphometric Alterations in Testes and Nuclei of Testicular Accessory Cells of Adults. J. Agric. Sci., 11(1), 410-417. https://doi.org/10.5539/jas.v11n1p410

Cremonez, P. S. G., Pinheiro, D. O., Falleiros, A. M. F., \& Neves, P. M. O. J. (2017). Performance of reproductive system of Dichelops melacanthus (Hemiptera: Pentatomidae) subjected to buprofezin and pyriproxyfen: morphological analysis of ovarioles and testes. Semin Cienc Agrar., 38(4), 2279-2292. https://doi.org/10.5433/1679-0359.2017v38n4Sup11p2279

Cremonez, P. S. G., Matsumoto, J. F., Andrello, A. C., Roggia, S., Pinheiro, D. O., \& Neves, P. M. O. J. (2019b). Macro-elements in the hemolymph of adult Euschistus heros (Fabr.) (Hemiptera: Pentatomidae) treated with pyriproxyfen. Comp. Biochem. Physiol. C Toxicol. Pharmacol., 220, 47-51. https://doi.org/10.1016/ j.cbpc.2019.02.012

Depieri, R. A., Siqueira, F., \& Panizzi, A. R. (2010). Aging and food source effects on mandibular stylets teeth wear of phytophagous stink bug (Heteroptera: Pentatomidae). Neotrop Entomol., 39(6), 952-956. https://doi.org/10.1590/S1519-566X2010000600017

Geneser, F. (2004). Histologia: Com bases biomoleculares (3rd ed.). Guanabara Koogan, Rio de Janeiro.

Guo, W., Wu, Z., Song, J., Jiang, F., Wang, Z., Deng, S., ... Zhou, S. (2014). Juvenile hormone-receptor complex acts on $\mathrm{Mcm} 4$ and $\mathrm{Mcm} 7$ to promote polyploidy and vitellogenesis in the migratory locust. PLoS Genet., 10(10), e1004702. https://doi.org/10.1371/journal.pgen.1004702

Hanifi, A., Mccarthy, H., Roberts, S., \& Pleshko, N. (2013). Fourier Transform Infrared Imaging and Infrared Fiber Optic Probe Spectroscopy Identify Collagen Type in Connective Tissues. PloS One, 8(5), e64822. https://doi.org/10.1371/journal.pone.0064822

Kusmirek, J. E., \& Kanne, J. P. (2019). Thoracic Manifestations of Connective Tissue Diseases. Seminars in Ultrasound CT MRI, 40(3), 239-254. https://doi.org/10.1053/j.sult.2018.12.003

Li, K., Jia, Q. Q., \& Li, S. (2019). Juvenile hormone signaling-A mini review. Insect Sci., 26(4), 600-606. https://doi.org/10.1111/1744-7917.12614

Manaboon, M., Yasanga, T., Sakurai, S., \& Singtripop, T. (2012). Programmed cell death of larval tissues induced by juvenile hormone in the bamboo borer, Omphisa fuscidentalis. J. Insect Physiol., 58(9), 1202-1208. https://doi.org/10.1016/j.jinsphys.2012.06.004

Mescher, A. L. (2018). Junqueira's Basic Histology: Text and Atlas (15th ed.). McGraw-Hill Education/Medical, New York, US.

Nauen, R., Slater, R., Sparks, T. C., Elbert, A., \& Mccaffery, A. (2019). IRAC: Insecticide resistance and mode-of-action classification of insecticides, In P. Jeschke, M. Witschel, W. Krämer, \& U. Schirmer (Eds.), Modern Crop Protection Compounds (3rd ed., pp. 995-1012). Weinheim: Willey-VCH. https://doi.org/ 10.1002/9783527699261.ch28

Pedersen, K. J. (1991). Invited review: structure and composition of basement membranes and other basal matrix systems in selected invertebrates. Acta Zool., 72(4), 181-201. https://doi.org/10.1111/j.1463-6395. 1991.tb01196.x

Pener, M. P., \& Dhadialla, T. S. (2012). An overview of insect growth disruptors; applied aspects. Advances in Insect Physiology (pp. 1-162). Oxford: Academic Press. https://doi.org/10.1016/B978-0-12-3915009.00001-2

Reddi, A. H., Gay, R., Gay, S., \& Miller, E. J. (1977). Transitions in collagen types during matrix-induced cartilage, bone, and bone marrow formation. Proc. Natl. Acad. Sci., 74(12), 5589-5592. https://doi.org/ 10.1073/pnas.74.12.558

Samantsidis, G. R., Panteleri, R., Denecke, S., Kounadi, S., Christou, I., Nauen, R., ... Vontas, J. (2020). 'What I cannot create, I do not understand': functionally validated synergism of metabolic and target site insecticide resistance. Proc. Royal Soc. B., 287, 20200838. https://doi.org/10.1098/rspb.2020.0838

Soares, P. L., Cordeiro, E. M. G., Santos, F. N. S., Omoto, C., \& Correa, A. S. (2018). The reunion of two lineages of the Neotropical brown Stink bug on soybean lands in the heart of Brazil. Sci Rep., 8, 2496. https://doi.org/10.1038/s41598-018-20187-6 
Souza, H. V., \& Itoyama, M. M. (2010). Comparative study of spermatogenesis and nucleolar behavior in testicular lobes of Euschistus heros (Heteroptera: Pentatomidae). Psyche., 2010(1), 1-10. https://doi.org/ $10.1155 / 2010 / 428673$

Vieira, S. S., Boff, M. I. C., Bueno, A. F., Gobbi, A. L., Lobo, R. V., \& Bueno, R. C. O. F. (2012). Efeitos dos inseticidas utilizados no controle de Bemisia tabaci (Gennadius) biótipo B e sua seletividade aos inimigos naturais na cultura da soja. Semin Cienc Agrar, 33(5), 1809-1818. https://doi.org/10.5433/1679-0359. 2012v33n5p1809

Wilmes, A. C., Klinke, N., Rotstein, B., Meyer, H., \& Paululat, A. (2018). Biosynthesis and assembly of the Collagen IV-like protein Pericardin in Drosophila melanogaster. Biology Open, 7(4), bio030361. http://10.0.4.218/bio.030361

Zara, F. J., \& Caetano, F. H. (2002). Ultrastructure of the salivary glands of Pachycondyla (= Neoponera) villosa (Fabricius) (Formicidae: Ponerinae): functional changes during the last larval instar. Cytologia, 67(3), 267-280. https://doi.org/10.1508/cytologia.67.267

\section{Copyrights}

Copyright for this article is retained by the author(s), with first publication rights granted to the journal.

This is an open-access article distributed under the terms and conditions of the Creative Commons Attribution license (http://creativecommons.org/licenses/by/4.0/). 